\title{
Subcutaneous Magnesium Sulfate to Correct High-Output Ileostomy-Induced Hypomagnesemia
}

\author{
Mark J. Makowsky a, b Peter Bell ${ }^{b} \quad$ Leah Gramlich $^{c}$ \\ aFaculty of Pharmacy and Pharmaceutical Sciences, University of Alberta, \\ Edmonton, AB, Canada; ${ }^{b}$ Department of Family Medicine, Faculty of Medicine and \\ Dentistry, University of Alberta, Edmonton, $A B$, Canada; 'Division of Gastroenterology, \\ Faculty of Medicine and Dentistry, University of Alberta, Edmonton, AB, Canada
}

\section{Keywords}

Magnesium · Subcutaneous infusions · Hypodermoclysis · Radiation enteritis · lleostomy

\begin{abstract}
Fluid and magnesium abnormalities are common in patients with high-output stomas. Subcutaneous magnesium administration may be more feasible for long-term management in ambulatory patients, but magnesium sulfate is approved only for intravenous or intramuscular injection. We describe the management of chronic hypomagnesemia and dehydration secondary to a high-output ileostomy following radiation and chemotherapy for anal squamous cell carcinoma with intermittent home-based subcutaneous magnesium infusions in a 61-year-old female with a history of Crohn's disease and multiple bowel resections. Despite aggressive management with intravenous magnesium sulfate and oral magnesium glucoheptonate over 8 months, $49 \%$ of her magnesium concentrations were $<0.60 \mathrm{mmol} / \mathrm{L}$ (mean $0.61 \pm 0.09$ ) necessitating 4 emergency, 1 hospital, and 4 infusion clinic visits. After initiation of subcutaneous magnesium sulfate, all magnesium concentrations were $>0.60 \mathrm{mmol} / \mathrm{L}$ (mean $0.79 \pm 0.08$ $\mathrm{mmol} / \mathrm{L}$ over 9 months). The patient tolerated the infusions well, only developing one minor
\end{abstract}




\section{Case Reports in Gastroenterology}

Case Rep Gastroenterol 2019;13:280-293

DOI: $10.1159 / 00050112$

(c) 2019 The Author(s). Published by S. Karger AG, Base www.karger.com/crg

Makowsky et al.: Subcutaneous Magnesium Sulfate

episode of infusion-related cellulitis. A systematic review of the literature identified 14 reports where subcutaneous magnesium sulfate was effective and treatment for adults or children with hypomagnesemia was safe. Home-based intermittent administration of subcutaneous magnesium may be a helpful and safe intervention to temporarily prevent and treat select patients with recurrent symptomatic hypomagnesemia.

(C) 2019 The Author(s)

Published by S. Karger AG, Basel

\section{Introduction}

Patients with intestinal failure secondary to a short bowel commonly experience hypomagnesemia, salt and water depletion, undernutrition, and vitamin/mineral deficiencies [1]. Sodium and water depletion may be severe in patients with high-output stomas and may necessitate restriction of hypotonic fluids, drinking an oral glucose-saline solution, antimotility drugs, and proton pump inhibitors or octreotide [2]. Hypomagnesemia secondary to high ostomy output may be treated by correcting water and sodium depletion, oral or intravenous doses of magnesium, or occasionally oral 1-alpha hydroxycholecalciferol $[1,3]$. While intravenous and oral magnesium supplements are recommended in patients with high-output stomas [2], replacement with oral magnesium supplements is difficult as most magnesium salts are poorly absorbed, and they may cause diarrhea [4, 5].

In some patients with high-output stomas, intravenous or subcutaneous saline may be needed to maintain fluid and sodium balance [1]. Clinical practice guidelines have suggested that $4 \mathrm{mmol}$ magnesium sulfate may be added to $500-1,000 \mathrm{~mL}$ of saline and be given subcutaneously 1-3 times a week if needed $[1,6]$. While other narrative reviews also support this practice if the oral, intravenous, or intramuscular routes are not available [7, 8], in Canada and other jurisdictions, magnesium sulfate is approved for intravenous or intramuscular administration only [9].

We report a case of successful correction and maintenance of normal magnesium concentrations with home-based intermittent subcutaneous magnesium infusions in a 61-year-old female with severe symptomatic hypomagnesemia secondary to a high-output ileostomy for Crohn's disease exacerbated by chemoradiation therapy for anal squamous cell cancer. Additionally, we systematically review the literature describing the use of subcutaneous magnesium supplementation to correct hypomagnesemia in patients with short bowel syndrome or other gastrointestinal conditions as well as hypomagnesemia of other causes.

\section{Case Report}

A 61-year-old female with colonic and perianal Crohn's disease, a chronic nonhealing wound in the perineum, a 4-month history of anal squamous cell carcinoma treated with combination chemoradiation presented to her family physician with a 10-day history of diffuse paresthesia and numbness on October 6, 2016, approximately 5 weeks following discharge from the local cancer center.

Originally diagnosed with Crohn's disease at 19 years of age, she had undergone 4 previous bowel resections with the last one at the age of 49 . She presented with a perineal mass on 
May 6, 2016 and began outpatient mitomycin C and 5 -fluorouracil with daily radiation treatments directed to the pelvis and anal canal on June 27. She completed 18 of 30 radiotherapy fractions as an outpatient but was admitted to the local cancer center on July 23 for management of pain associated with radiation desquamation and significant metabolic abnormalities including dehydration, hypotension, and hypomagnesemia related to a high-output ileostomy. Her radiotherapy was completed on August 10 and at discharge on August 30, she was using loperamide 2-4 mg orally b.i.d. and psyllium b.i.d. p.r.n. to regulate her ostomy output, was on morphine $15 \mathrm{mg}$ orally every $4 \mathrm{~h}$ and $10 \mathrm{mg}$ orally every $1 \mathrm{~h}$ p.r.n. for pain control and a variety of oral supplements (vitamin D 2,000 IU daily, zinc $50 \mathrm{mg}$ daily, selenium $50 \mathrm{mg}$ daily, calcium $1,000 \mathrm{mg}$ daily, centrum multivitamin b.i.d.).

After presenting on October 6, she was found to have several electrolyte and fluid imbalances including hypomagnesemia $(0.41 \mathrm{mmol} / \mathrm{L})$, hypokalemia $(3.1 \mathrm{mmol} / \mathrm{L})$, elevated serum creatinine (123 mmol/L; estimated glomerular filtration rate [eGFR] $\left.41 \mathrm{~mL} / \mathrm{min} / 1.73 \mathrm{~m}^{2}\right)$, total calcium $1.82 \mathrm{mmol} / \mathrm{L}$ (albumin $37 \mathrm{~g} / \mathrm{L}$ ), and her symptoms were successfully managed in the emergency department with a 2-g intravenous bolus dose of magnesium sulfate (Fig. 1). There she was prescribed $75 \mathrm{mg}$ ( $3 \mathrm{mmol}$ ) of elemental magnesium orally twice daily as magnesium glucoheptonate $1,500 \mathrm{mg} / 15 \mathrm{~mL}$ b.i.d. and calcium carbonate $500 \mathrm{mg}$ b.i.d. Subsequent monitoring indicated an increase in her magnesium concentrations over the course of the next month, but she continued to empty her ostomy approximately 12 times per day and her serum creatinine $\left(151 \mathrm{mmol} / \mathrm{L}\right.$; eGFR: $\left.32 \mathrm{~mL} / \mathrm{min} / 1.73 \mathrm{~m}^{2}\right)$ indicated prerenal renal insufficiency.

On November 8, home subcutaneous normal saline infusions (1 L over 8-12 h overnight) were started and her psyllium and loperamide therapy were increased to $4 \mathrm{mg}$ q.i.d, while she continued magnesium glucoheptonate $1,500 \mathrm{mg}$ magnesium orally b.i.d. Over the next 10 weeks, her eGFR improved, stabilizing in the $40-50 \mathrm{~mL} / \mathrm{min} / 1.73 \mathrm{~m}^{2}$ range, her magnesium glucoheptonate was titrated up to $3,000 \mathrm{mg}$ (150 $\mathrm{mg}$ [6 mmol] orally t.i.d. in response to dropping magnesium concentrations [0.49 mmol/L on November 22]), and Codeine Contin was added and titrated up to $100 \mathrm{mg}$ b.i.d. Despite this, over the next month, her magnesium concentrations showed a downward trend and on January 23, 2017, her magnesium was 0.46 $\mathrm{mmol} / \mathrm{L}$ and she received a 2-g intravenous bolus dose of magnesium sulfate in the emergency department on January 25. She continued to have high ostomy output (i.e., $300-400 \mathrm{~mL}$ every 2-3 h) and on February 1, pantoprazole $40 \mathrm{mg}$ daily was added, cholestyramine was prescribed in place of psyllium, stool cultures were collected (subsequently Clostridium difficile negative), and she was booked for upper endoscopy/ileoscopy to evaluate for recurrence of Crohn's disease.

While her family physician was arranging intermittent intravenous magnesium sulfate boluses at the hospital-based infusion clinic, her magnesium level continued downward to $0.43 \mathrm{mmol} / \mathrm{L}$ and she received $2 \mathrm{~g}$ of magnesium sulfate intravenously in the emergency department on February 24 and 26. After receiving a third dose of $2 \mathrm{~g}$ magnesium sulfate intravenously at the infusion clinic on March 2, she was electively admitted to the Inpatient Gastroenterology Service to expedite the investigation of her high-output ileostomy/hypomagnesemia and there received another dose of intravenous magnesium sulfate. Endoscopy showed mild gastritis, ileostomy and computed tomography enterography ruled out recurrent Crohn's disease, and her urine magnesium level was $<0.40 \mathrm{mmol} / \mathrm{L}$ ruling out renal losses. Radiation enteritis was the presumed diagnosis on discharge (March 6) and no changes 
were made to her medications except pantoprazole was discontinued. Three weeks later (March 27), her magnesium was $0.55 \mathrm{mmol} / \mathrm{L}$ and another dose of magnesium sulfate $2 \mathrm{~g}$ was administered at the infusion clinic. On April 21, a consultant nephrologist suggested adding magnesium sulfate to her home subcutaneous fluid. While the feasibility of this recommendation was being explored, the patient had an emergency department visit on June 2 for general weakness and required two further 2 -g bolus doses of magnesium sulfate at the infusion clinic on May 24 and July 5.

On July 19,2017 , the patient returned to the family medicine clinic to discuss initiating home subcutaneous magnesium sulfate supplementation. The patient agreed and was instructed to add magnesium sulfate $1 \mathrm{~g}$ (i.e., 4 mmol elemental $\mathrm{Mg}^{2+} ; 5 \mathrm{~mL} 200 \mathrm{mg} / \mathrm{L}$ magnesium sulfate) to her $500 \mathrm{~mL}$ normal saline infusion on 2 consecutive days, take 1 day off, then repeat the dose on the following 2 consecutive days. The clinic registered nurse instructed the patient on how to prepare and administer the infusion overnight. One week later, on July 25, her magnesium level was $0.88 \mathrm{mmol} / \mathrm{L}$. She tolerated the infusions well with only a minor burning sensation and no significant side effects. After 2 more doses, her next magnesium level on July 31 was $0.87 \mathrm{mmol} / \mathrm{L}$. During the following week, she took 2 serial doses followed by 3 days off and her next magnesium level on August 8 was maintained at $0.86 \mathrm{mmol} / \mathrm{L}$. As shown in Figure 1, subsequent subcutaneous magnesium infusions on 2 days on a 3 -days-off schedule were successful in maintaining magnesium concentrations $>0.7 \mathrm{mmol} / \mathrm{L}$ for the next 6 weeks.

Due to a continued high output from her ileostomy (i.e., $300 \mathrm{~mL}, 12-15$ times per day), the patient was assessed at the GI Malnutrition Clinic on September 22. Tethering of the bowel secondary to radiation, abnormal motility related to multiple previous surgeries, and bacterial overgrowth were suspected. She was started on a course of cyclical ciprofloxacin $500 \mathrm{mg}$ b.i.d. and metronidazole $500 \mathrm{mg}$ b.i.d., 2 weeks on and 1 week off, and restarted pantoprazole 40 mg twice daily. Her other therapies were unchanged.

The patient continued to tolerate the subcutaneous magnesium infusions well. However, on October 10, during a preoperative medical treatment for perineal wound closure, she complained of a 1-day history of pain and erythema on the left side of her abdomen where she last had her infusion, chills, and had a temperature of $38.0^{\circ} \mathrm{C}$. She was treated for a presumed early cellulitis with a 7-day course of oral cephalexin.

In follow-up at the Malnutrition Clinic on November 3, the patient reported emptying her ileostomy less frequently and was advised to continue the cyclical antibiotics. As her magnesium was $0.67 \mathrm{mmol} / \mathrm{L}$ and renal function was stable (eGFR $=50 \mathrm{~mL} / \mathrm{min} / 1.73 \mathrm{~m}^{2}$ ), she continued subcutaneous magnesium infusions but switched to oral magnesium glycinate 2,000 $\mathrm{mg}$ (200 mg [8 mmol] elemental magnesium) 2 tablets three times daily from magnesium glucoheptonate. Between November 21 and December 7, the patient was admitted to hospital for elective closure of her perineal wound. At her third visit to the Malnutrition Clinic (January 12,2018 ), her weekly magnesium concentrations were noted to be between 0.73 and 0.92 $\mathrm{mmol} / \mathrm{L}$ and she was advised to reduce the frequency of magnesium infusions to 2 days on 4 days off and to start a trial of cutaneous magnesium lotion.

On follow-up, at the Malnutrition Clinic on May 18, her subcutaneous magnesium infusions were stopped as her ileostomy output was $<2 \mathrm{~L}$ per day and her magnesium levels were consistently $>0.7 \mathrm{mmol} / \mathrm{L}$. For the next 4 months, she consistently maintained magnesium levels above $0.7 \mathrm{mmol} / \mathrm{L}$ with oral magnesium glycinate therapy. However, she still required 


\section{Case Reports in Gastroenterology}

Case Rep Gastroenterol 2019;13:280-293

DOI: $10.1159 / 00050112$

(C) 2019 The Author(s). Published by S. Karger AG, Basel www.karger.com/crg

Makowsky et al:: Subcutaneous Magnesium Sulfate

ongoing subcutaneous parenteral saline $500 \mathrm{~mL}$ daily to maintain fluid status. As of the time of writing in March 2019, her most recent magnesium was $0.77 \mathrm{mmol} / \mathrm{L}$ and she remains off subcutaneous magnesium supplementation.

\section{Discussion}

Our case report adds to the existing literature, which suggests that subcutaneous magnesium sulfate is safe and effective in normalizing serum magnesium levels and reversing symptomatic hypomagnesemia in patients with severe refractory hypomagnesemia secondary to gastrointestinal, congenital, or medication induced causes. A systematic literature search (online suppl. Appendix 1; for all online suppl. material, see www. karger.com/doi/10.1159/000501121) to identify original research describing subcutaneous administration of magnesium (sulfate) in adults or children yielded 14 publications meeting our inclusion criteria [10-23] (Fig. 2; Table 1, Table 2, Table 3, Table 4). A total of 5 case reports $[10-13,17]$ and 3 publications reporting 2 retrospective case series [14-16] described experiences of patients with gastrointestinal conditions using subcutaneous magnesium supplementation. Seven case reports were identified in nongastrointestinal conditions [18-24] but one was excluded as there was no English language abstract and the full text was only available in German [24]. We excluded reports describing the use of subcutaneous magnesium for other conditions including tetanus [25, 26], hydrofluoric acid burns [27, 28], and pain [2932].

\section{Reports in Patients with Gastrointestinal Conditions}

The 7 available reports detailed in the tables (Table 1, Table 2, Table 3, Table 4) describe administration of subcutaneous magnesium to correct refractory hypomagnesemia to 63 adults with a variety of gastrointestinal conditions leading to gastrointestinal failure. They were published between 1991 and 2018 with the majority of reports from the UK $(n=4)$. In 5 of the 7 reports, subcutaneous magnesium was prepared in a bag of intravenous fluids and infused intermittently. For the intermittent subcutaneous infusions, the dose of magnesium ranged from 2 to $12 \mathrm{mmol}$ of magnesium per bag but most commonly was in the 2 to $8 \mathrm{mmol} / \mathrm{L}$ range. The duration of the infusions was between 6 and $12 \mathrm{~h}$ and they were typically given overnight. The frequency of infusion ranged between 2 and 7 days per week. In the 2 publications that reported typical weekly doses, the ranges were 8-28 mmol magnesium sulfate/week [11] and a mean of $21 \pm 9.8$ (range 8-40) mmol per week [14]. Two reports addressed duration of therapy. McDermott et al. [10] reported a total of 24 months of therapy, while Small et al. [14] noted average treatment durations of $17.4 \pm 34$ and $10 \pm 8.5$ months for those receiving 4 and $8 \mathrm{mmol}$ of magnesium per infusion, respectively.

In two cases, subcutaneous magnesium was administered via a syringe pump $[10,17]$. In one, a microinfusion pump was used and $14 \mathrm{mmol}(8 \mathrm{~mL})$ of magnesium sulfate was added to $7 \mathrm{~mL}$ of sterile water and infused over $10 \mathrm{~h}$ overnight [10]. In the second, a CME T34 (McKinley syringe pump) with one 50-mL syringe daily was used to deliver $8 \mathrm{mmol}$ magnesium sulfate (i.e., $4 \mathrm{~mL}$ of magnesium sulfate $50 \%$ injection) made up to $32 \mathrm{~mL}$ with water for injection to provide an isotonic solution. The success of treatment in normalizing serum magnesium concentrations was reported in all 7 publications and only 2 individual cases of unsuccessful 


\section{Case Reports in Gastroenterology} \begin{tabular}{l|l}
\hline Case Rep Gastroenterol 2019;13:280-293 \\
\hline DOI: 10.1159/000501121 & $\begin{array}{l}\text { @ } 2019 \text { The Author(s). Published by S. Karger AG, Basel } \\
\text { www.karger.com/crg }\end{array}$ \\
\hline
\end{tabular}

Makowsky et al.: Subcutaneous Magnesium Sulfate

response to subcutaneous magnesium supplementation were reported. Symptomatic improvement was reported in 3 out of the 7 papers $[10,11]$, while the remaining 5 did not report this outcome. Local or systemic adverse effects were discussed in 5 out of the 7 reports, with superficial skin abscesses, transient local edema that resolved with reducing the rate of infusion, and cellulitis at the needle insertion site noted.

\section{Reports in Other Conditions}

The 6 included case reports describe administration of subcutaneous magnesium to 5 adults and 1 child with a variety of medical conditions necessitating magnesium supplementation including congenital causes of hypomagnesemia [18, 19, 21, 22], in the hospice/palliative care context [20], and in cisplatin-induced hypomagnesemia [23] (Table 1, Table 2, Table 3 , Table 4). These were published between 2000 and 2017, with 2 reports from Germany [18, 19], 2 from the United States [20, 21], and 1 each from Switzerland [22] and the Netherlands [23]. Continuous infusions via an infusion pump were used in 5 of the 6 reports [18, 20-23], and in the remaining report it was unclear how magnesium was delivered [19]. Dosing information for the continuous infusions were only reported in 3 of the 5 cases and are detailed in the tables (Table 1, Table 2, Table 3, Table 4). The duration of therapy was reported in 3 cases as 2 days [20], at least 6 months [22] and 2 years [23]. The effect on serum magnesium concentrations was reported in 4 of 7 cases and success in normalizing levels was reported in all 4 cases $[18,21,22]$. Impact on symptoms was reported in 4 cases and in all cases most symptoms were deemed to be improved or resolved [18, 19, 22, 23]. In 1 case, no skin irritation was reported [20], while in 2 reports, subcutaneous infections [22] or mild skin lesions and nonpainful indurated areas [23] were noted at the insertion site.

While we were unable to definitively establish that subcutaneous magnesium therapy corrected our patient's hypomagnesemia, 20 out of 41 (49\%) of her routine magnesium levels were $<0.6 \mathrm{mmol} / \mathrm{L}$ (mean $\pm \mathrm{SD}=0.61 \pm 0.09 \mathrm{mmol} / \mathrm{L}$ ), and she had 4 emergency visits, 1 hospital admission, and 4 infusion clinic visits related to hypomagnesemia during treatment with oral and intravenous bolus magnesium. In contrast, she had no concentrations $<0.6 \mathrm{mmol} / \mathrm{L}$ (mean $0.79 \pm 0.08 \mathrm{mmol} / \mathrm{L}$ ) and 1 minor episode of infusion-related cellulitis during 10 months of home-based subcutaneous therapy, while her eGFR was similar in both periods ( 50.4 vs. $49.1 \mathrm{~mL} / \mathrm{min} / 1.73 \mathrm{~m}^{2}$ ). However, improved magnesium levels could be explained by better management of her ostomy output with cyclic antibiotic therapy and dietary counselling, which led to the eventual ability to stop parenteral magnesium therapy altogether. The use of oral magnesium glycinate rather than oral magnesium glucoheptonate in addition to optimization of her antimotility therapy, codeine, and proton pump inhibitor may also have contributed.

Notably, our use of a home compounded magnesium solution is not consistent with new USP 797 standards for pharmaceutical compounding and we would recommend preparation by a compounding pharmacy using an ISO 5 environment. In this context, $500 \mathrm{~mL}$ normal saline bags may be stored refrigerated for 9-14 days after the magnesium is added [33, 34].

In conclusion, the intermittent administration of subcutaneous magnesium sulfate in conjunction with hydration fluid administered at home may be a helpful and safe but underrecognized intervention to maintain serum magnesium levels in patients with high-output ostomies and recurrent hypomagnesemia in clinical practice. In appropriate patients, this strategy 
may help to avoid repeated emergency department visits, hospital admissions, and infusion clinic visits for intravenous magnesium supplementation.

\section{Acknowledgement}

The authors wish to acknowledge Ms. Janice Kung, Health Sciences Librarian, John W. Scott, Health Sciences Library, University of Alberta for conducting the literature search, and Dr. Ken Cor, Clinical Research Associate Professor, Faculty of Pharmacy and Pharmaceutical Sciences, University of Alberta for assisting with the statistical analysis.

\section{Statement of Ethics}

The patient has provided written informed consent to publish this case.

\section{Disclosure Statement}

The authors have no conflicts of interest to declare.

\section{Funding Sources}

There were no funding sources for preparation of the manuscript.

\section{Author Contributions}

Contributing to the conception and design: M.J. Makowsky, P. Bell. Analysis and interpretation of data: M.J. Makowsky, L. Gramlich. Drafting of initial manuscript: M.J. Makowsky. Critical revision of manuscript for intellectual content: M.J. Makowsky, P. Bell, L. Gramlich. Approval of the final manuscript: M.J. Makowsky, P. Bell, L. Gramlich.

\section{References}

1 Nightingale J, Woodward JM; Small Bowel and Nutrition Committee of the British Society of

Gastroenterology. Guidelines for management of patients with a short bowel. Gut. 2006 Aug;55 Suppl 4:iv112.

2 Baker ML, Williams RN, Nightingale JM. Causes and management of a high-output stoma. Colorectal Dis. 2011 Feb;13(2):191-7.

3 Fukumoto S, Matsumoto T, Tanaka Y, Harada S, Ogata E. Renal magnesium wasting in a patient with short bowel syndrome with magnesium deficiency: effect of 1 alpha-hydroxyvitamin D3 treatment. J Clin Endocrinol Metab. 1987 Dec;65(6):1301-4.

4 Medlin S. Nutritional and fluid requirements: high-output stomas. Br J Nurs. 2012 Mar;21(6):S22-5. 
5 Lennard-Jones JE. Review article: practical management of the short bowel. Aliment Pharmacol Ther. 1994 Dec;8(6):563-77.

6 Banerjee A, Warwicker P. Acute renal failure and metabolic disturbances in the short bowel syndrome. QJM. 2002 Jan;95(1):37-40.

7 Midgley S; Leeds Medicines Information Centre. How is acute hypomagnesaemia treated in adults? 2016 [accessed 2018 Jan 31]. Available from: https://www.sps.nhs.uk/articles/how-is-acute-hypomagnesaemiatreated-in-adults/.

8 McKie J. Can magnesium sulfate be given subcutaneously?Southampton Medicines Advice Service, University Hospital Southampton NHS Foundation Trust; 2016. Available from: https://www.sps.nhs.uk/articles/canmagnesium-sulfate-be-given-subcutaneously-2/.

9 Fresenius Kabi. Magnesium Sulfate Injection - Package Insert [accessed 2018 Jan 31]. Available from: https://www.fresenius-kabi.com/en-ca/documents/Mag-Sulfate-PI-Eng-v1.1-Clean.pdf.

10 McDermott KC, Almadrones LA, Bajorunas DR. The diagnosis and management of hypomagnesemia: a unique treatment approach and case report. Oncol Nurs Forum. 1991 Sep-Oct;18(7):1145-52.

11 Martínez-Riquelme A, Rawlings J, Morley S, Kendall J, Hosking D, Allison S. Self-administered subcutaneous fluid infusion at home in the management of fluid depletion and hypomagnesaemia in gastro-intestinal disease. Clin Nutr. 2005 Feb;24(1):158-63.

12 Tsao SK, Baker M, Nightingale JM. High-output stoma after small-bowel resections for Crohn's disease. Nat Clin Pract Gastroenterol Hepatol. 2005 Dec;2(12):604-8.

13 Alfaro Martínez JJ, Botella Romero F, Lamas Oliveira C, Hernández López A. Severe hypocalcemia secondary to hypomagnesaemia, successfully treated by self-administered subcutaneous magnesium. Nutr Hosp. 2009 May-Jun;24(3):354-6.

14 Small M, Brundrett D, Nightingale J. PWE-235 Long term subcutaneous saline and magnesium administration in patients with a short bowel. 10 Year outcomes. Gut. 2015;64 Supp 1:A1-584.

15 Small M, Brundrett D, Nightingale J. Long term subcutaneous saline and magnesium administration in patients with a short bowel - 10-year outcomes. Clin Nutr. 2015;34 SUPPL 1:S120.

16 Adgey C, McKenna C, Murray E, Graham T, Gerard R. Home subcutaneous fluids for Mmagnesium stabilisation - a review of patients in the Belfast trust (Poster 15W113) [accessed 2018 Jan 31]. Available from: https://www.isge.ie/abstracts/view/49/.

17 Fenning SJ, Boyce SR, Wilson P, Stretton F. Subcutaneous magnesium in the advanced cancer setting. BMJ Support Palliat Care. 2018 Jun;8(2):191-3.

18 Aries PM, Schubert M, Müller-Wieland D, Krone W. [Subcutaneous magnesium pump in a patient with combined magnesium transport defect]. Dtsch Med Wochenschr. 2000 Aug;125(33):970-2.

19 Weinbrenner A, Besser R. Epileptic seizures and cerebellar ataxia resulting from primary hypomagnesemia and secondary hypocalcemia in an adult female. Akt Neurol. 2006 Oct;33(8):467-71.

20 Pirrello RD, Ting Chen C, Thomas SH. Initial experiences with subcutaneous recombinant human hyaluronidase. J Palliat Med. 2007 Aug;10(4):861-4.

21 Sanda S, Schlingmann KP, Newfield RS. Autosomal dominant hypoparathyroidism with severe hypomagnesemia and hypocalcemia, successfully treated with recombinant PTH and continuous subcutaneous magnesium infusion. J Pediatr Endocrinol Metab. 2008 Apr;21(4):385-91.

22 Bock A, Roth S. Continuous subcutaneous magnesium infusion by portable pump for severe congenital hypomagnesaemia. Swiss Med Wkly. 2013;143 SUPPL 202:18S.

23 Vermeulen EA, Vervloet MG, Lubach CH, Nurmohamed SA, Penne EL. Feasibility of long-term continuous subcutaneous magnesium supplementation in a patient with irreversible magnesium wasting due to cisplatin. Neth J Med. 2017 Jan;75(1):35-8.

24 Mertz DP. [Subcutaneous magnesium pump in a patient with combined magnesium transport defect]. Dtsch Med Wochenschr. 2001 Jan;126(4):96.

25 Lyon M. Tetanus treated with magnesium sulphate by hypodermoclysis. J Am Med Assoc. 1908 Jun;50(Apr):1688.

26 Paterson P. A case of tetanus treated with subcutaneous injections of magnesium sulfate; Recovery. Lancet. 1910;175(4518):922-3.

27 Litovitz TL. The anecdotal antidotes. Emerg Med Clin North Am. 1984 Feb;2(1):145-58.

28 Gallerani M, Bettoli V, Peron L, Manfredini R. Systemic and topical effects of intradermal hydrofluoric acid. Am J Emerg Med. 1998 Sep;16(5):521-2.

29 Meynadier J. New medical treatment of neuropathic pain. Nowotwory. 2000;49 SUPPL 3:45-9.

30 Razavi SS, Peyvandi H, Badrkhani Jam AR, Safari F, Teymourian H, Mohajerani SA. Magnesium Versus Bupivacaine Infiltration in Controlling Postoperative Pain in Inguinal Hernia Repair. Anesth Pain Med. 2015 Dec;5(6):e30643. 


\section{Case Reports in Gastroenterology} \begin{tabular}{l|l}
\hline Case Rep Gastroenterol 2019;13:280-293 \\
\hline DOI: 10.1159/000501121 & $\begin{array}{l}\text { ○ 2019 The Author(s). Published by S. Karger AG, Basel } \\
\text { www.karger.com/crg }\end{array}$ \\
\hline
\end{tabular}

Makowsky et al: Subcutaneous Magnesium Sulfate

31 Kundra S, Singh RM, Singh G, Singh T, Jarewal V, Katyal S. Efficacy of Magnesium Sulphate as an Adjunct to Ropivacaine in Local Infiltration for Postoperative Pain Following Lower Segment Caesarean Section. J Clin Diagn Res. 2016 Apr;10(4):UC18-22.

32 Srebro D, Vučković S, Milovanović A, Košutić J, Vujović KS, Prostran M. Magnesium in pain research: state of the art. Curr Med Chem. 2016 Dec;24(4):424-34.

33 USP 797 - Briefing: Pharmaceutical Compounding - Sterile Preparations [accessed 2019 Feb 8]. Available from: https://www.uspnf.com/sites/default/files/usp_pdf/EN/USPNF/usp-gc-797-proposed-revisions-sep2015.pdf.

34 National Association of Pharmacy Regulatory Authorities. Model Standards for Pharmacy Compounding of Non Hazardous Sterile Preparations (revision November 2016) [accessed 2019 Feb 8]. Available from: https://napra.ca/sites/default/files/2017-

09/Mdl_Stnds_Pharmacy_Compounding_NonHazardous_Sterile_Preparations_Nov2016_Revised_b.pdf.

35 de Vries RM, Morey RD. Bayesian hypothesis testing for single-subject designs. Psychol Methods. 2013 Jun;18(2):165-85.

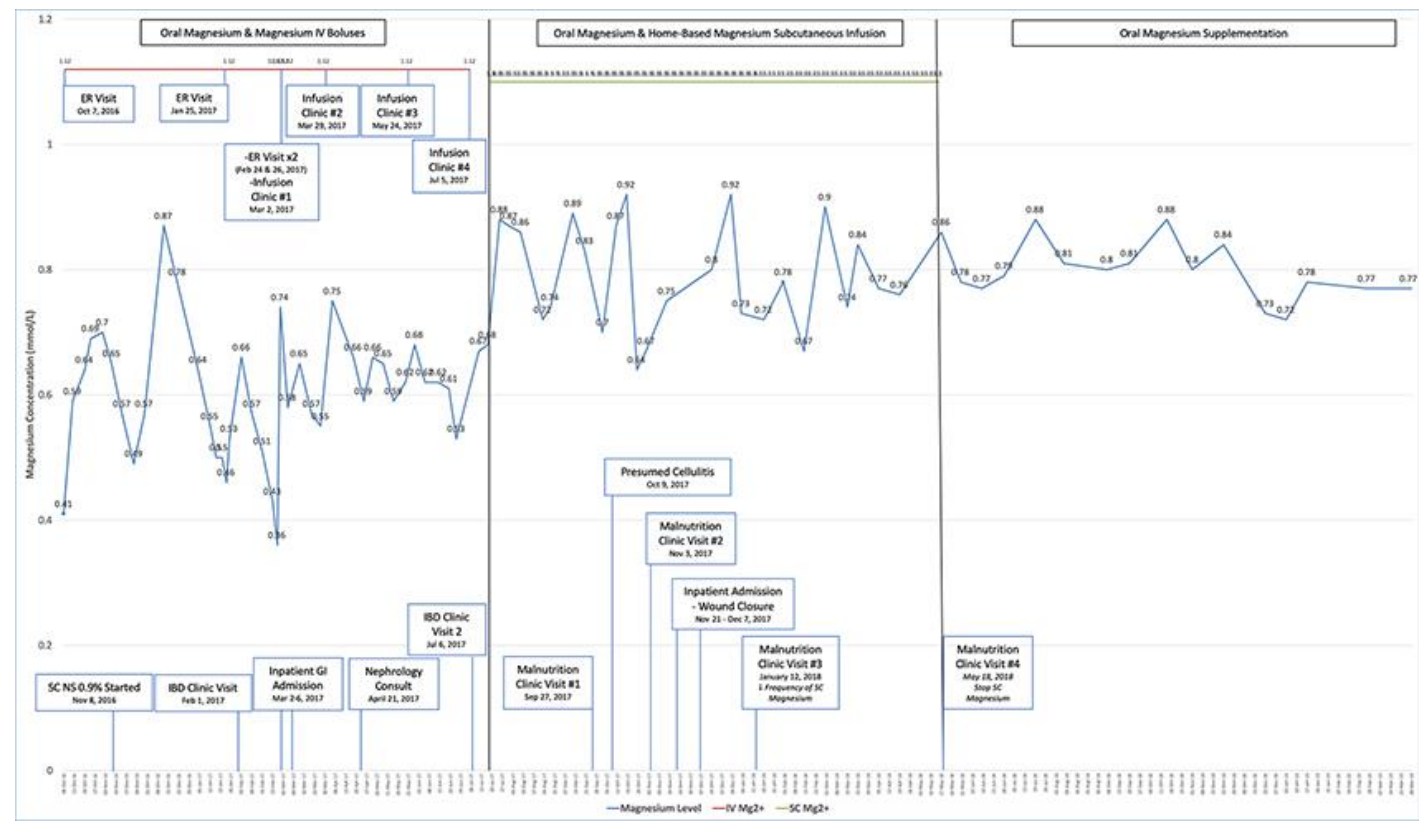

Fig. 1. Magnesium concentrations over time. Analysis of the mean difference in magnesium concentrations between the period on intravenous magnesium boluses (mean \pm SD pre: $0.61 \pm 0.09 \mathrm{mmol} / \mathrm{L}$ ) versus on subcutaneous home-based magnesium infusions (mean \pm SD post: $0.79 \pm 0.08 \mathrm{mmol} / \mathrm{L}$ ) using a bayesian single subject autoregressive approach (i.e., JZS + AR model) indicated that there was a true difference as a result of the intervention (bar $=8.903 \mathrm{e}-05$ ) [35]. ER, emergency room; IV, intravenous; SC, subcutaneous; NS, normal saline; IBD, inflammatory bowel disease; GI, gastrointestinal. 


\section{Case Reports in Gastroenterology}

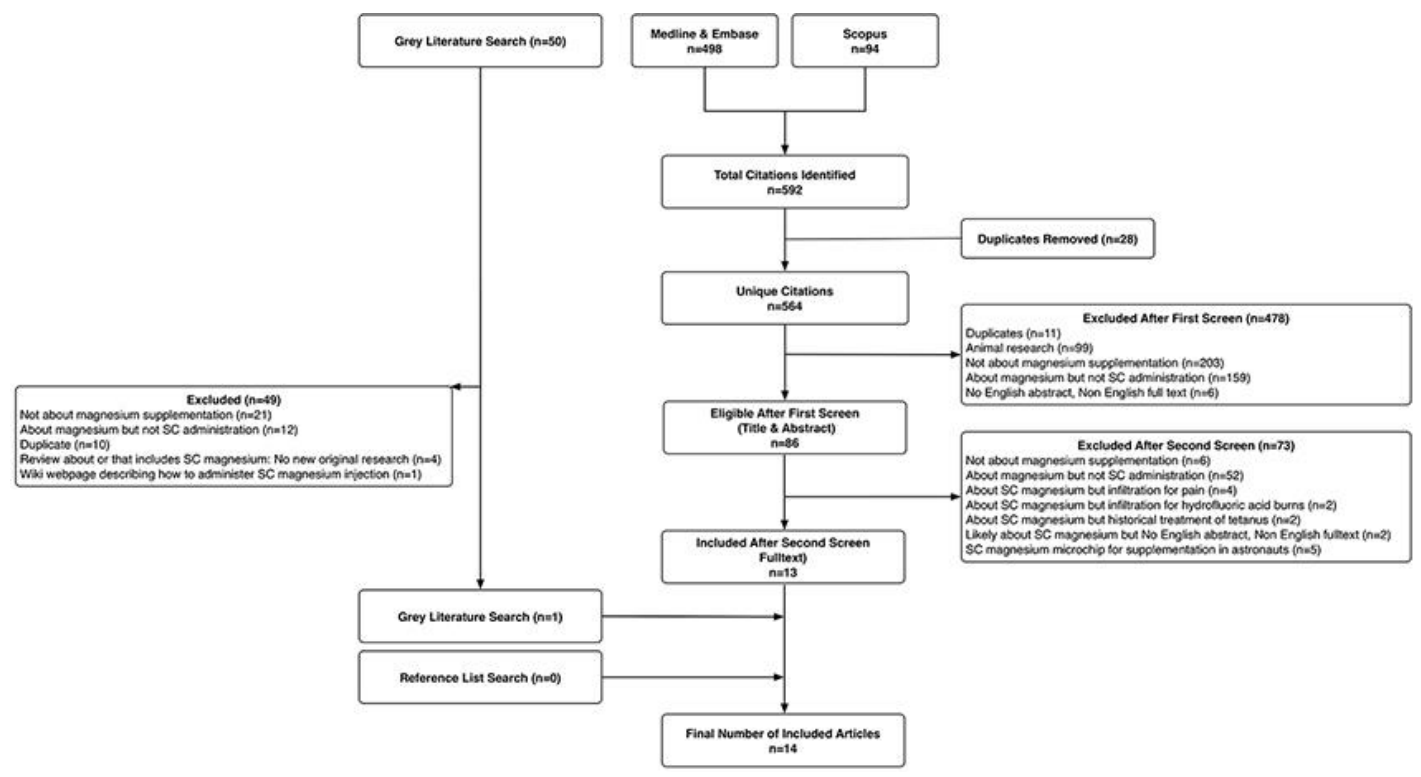

Fig. 2. Flow diagram. SC, subcutaneous. 


\section{Case Reports in Gastroenterology}

Makowsky et al.: Subcutaneous Magnesium Sulfate

Table 1. Summary of included reports describing subcutaneous magnesium administration

\begin{tabular}{|c|c|c|c|c|c|c|c|}
\hline Search & $\begin{array}{l}\text { Author, year of } \\
\text { publication }\end{array}$ & Design & Patients & Magnesium dose & $\begin{array}{l}\text { Influence on } \mathrm{Mg}^{2+} \text { and } \\
\text { symptoms }\end{array}$ & Adverse effects & Country \\
\hline \multicolumn{8}{|c|}{ Gastrointestinal conditions } \\
\hline $\mathrm{M} / \mathrm{E}$ & $\begin{array}{l}\text { McDermott et al. } \\
{[10], 1991}\end{array}$ & Case report & $\begin{array}{l}n=1 \\
63 \text { yrs old } \\
\text { Total regional pancreatec- } \\
\text { tomy }\end{array}$ & $\begin{array}{l}\text { The final dose was magne- } \\
\text { sium sulfate } \\
14 \mathrm{mmol}(8 \mathrm{~mL}) \text { and } \\
7 \mathrm{~mL} \text { of sterile water ad- } \\
\text { ministered subcutane- } \\
\text { ously via microinfusion } \\
\text { pump (Walkmed pump } \\
\text { (Medfusion, Duluth, GA, } \\
\text { USA); } 10 \text { h overnight } \\
\text { Duration: } 24 \text { months }\end{array}$ & $\begin{array}{l}\mathrm{Mg}^{2+}: \text { serum magne- } \\
\text { sium levels kept } \\
\text { within a low normal } \\
\text { range } \\
\text { Symptoms: improved }\end{array}$ & $\begin{array}{l}\text { On one occasion } \\
\text { two 1-cm dark col- } \\
\text { ored superficial } \\
\text { skin abscesses } \\
\text { were reported }\end{array}$ & $\begin{array}{l}\text { United } \\
\text { States }\end{array}$ \\
\hline $\mathrm{M} / \mathrm{E}$ & $\begin{array}{l}\text { Martínez- } \\
\text { Riquelme et al. } \\
{[11], 2005}\end{array}$ & Case series & $\begin{array}{l}n=10 \text { (mean age: } 65.3 \pm \\
13.5 \text { yrs) with GI failure } \\
\text { and adequate micronutri- } \\
\text { ent status who could not } \\
\text { maintain a positive salt, } \\
\text { water and magnesium bal- } \\
\text { ance; } \\
n=8 \text { received magnesium } \\
\text { sulfate supplementation }\end{array}$ & $\begin{array}{l}500-1,000 \mathrm{~mL} \text { of NS or } \\
\text { D5W with between } 2 \text { and } \\
4 \text { mmol of magnesium sul- } \\
\text { fate subcutaneously by } \\
\text { gravity drip over } 6-12 \mathrm{~h} \\
\text { (overnight) 3-7 days per } \\
\text { week (total dose } 8- \\
28 \text { mmol magnesium sul- } \\
\text { fate/week }\end{array}$ & $\begin{array}{l}M g^{2+}: \text { normal serum } \\
\text { Mg concentrations } \\
\text { were achieved within } \\
2 \text { weeks } \\
\text { Symptoms: mild par- } \\
\text { esthesia's resolved in } \\
2 \text { patients and several } \\
\text { reported improved } \\
\text { vigor and strength }\end{array}$ & $\begin{array}{l}\text { Three patients de- } \\
\text { veloped transient } \\
\text { local edema that } \\
\text { resolved with re- } \\
\text { ducing the rate of } \\
\text { infusion } \\
\text { No patient suffered } \\
\text { local infection or } \\
\text { other complica- } \\
\text { tions }\end{array}$ & $\begin{array}{l}\text { United King- } \\
\text { dom }\end{array}$ \\
\hline $\mathrm{M} / \mathrm{E}$ & $\begin{array}{l}\text { Tsao et al. [12], } \\
2005\end{array}$ & Case report & $\begin{array}{l}n=1 \\
56 \text {-year-old female with } \\
\text { Crohn's disease and multi- } \\
\text { ple bowel resections; hy- } \\
\text { pomagnesemia despite } \\
24 \text { mmol/day oral magne- } \\
\text { sium oxide }\end{array}$ & $\begin{array}{l}\text { Magnesium } 4 \text { mmol per } 1 \\
\text { L normal saline, twice } \\
\text { weekly }\end{array}$ & $\begin{array}{l}M^{2+}: \text { she maintained } \\
\text { her hydration and se- } \\
\text { rum } \mathrm{Mg}^{2+} \text { levels on } \\
\text { this regimen } \\
\text { Symptoms: not re- } \\
\text { ported }\end{array}$ & Not reported & $\begin{array}{l}\text { United King- } \\
\text { dom }\end{array}$ \\
\hline $\mathrm{M} / \mathrm{E}$ & $\begin{array}{l}\text { Alfaro Martínez } \\
\text { et al. [13], } 2009\end{array}$ & Case report & $\begin{array}{l}n=1 \\
71 \text {-year-old male; rectal } \\
\text { carcinoma, with recurrent } \\
\text { severe hypocalcemia sec- } \\
\text { ondary to hypomagnese- } \\
\text { mia and prerenal renal } \\
\text { failure after colectomy and } \\
\text { terminal ileostomy; } \\
\text { previous oral and IV mag- } \\
\text { nesium }\end{array}$ & $\begin{array}{l}\text { In hospital treatment: ini- } \\
\text { tial IV magnesium infu- } \\
\text { sion; on the second day he } \\
\text { was transferred to subcu- } \\
\text { taneous administration of } \\
\text { saline solution with mag- } \\
\text { nesium sulfate ( } 12 \text { mmol } \\
\text { of magnesium sulfate in } \\
1,000 \text { mL of saline solu- } \\
\text { tion during } \\
12 \text { h) via a butterfly nee- } \\
\text { dle } \\
\text { Outpatient treatment: Self- } \\
\text { administered subcutane- } \\
\text { ous infusion of } 500 \text { mL of } \\
\text { saline solution with } 6 \text { mEq } \\
\text { of magnesium sulfate dur- } \\
\text { ing } 6 \text { h per day; co-treat- } \\
\text { ment with oral calcium } \\
\text { gluconate, calcitriol, and } \\
\text { codeine } \\
\text { He was advised to in- } \\
\text { crease saline administra- } \\
\text { tion to } 1,000 \text { mL per day if } \\
\text { diuresis diminished or ile- } \\
\text { ostomy losses increased }\end{array}$ & $\begin{array}{l}\mathrm{Mg}^{2+}: \text { levels of serum } \\
\text { calcium, magnesium } \\
\text { and PTH normalized } \\
\text { Symptoms: patient } \\
\text { whose daily activities } \\
\text { were very limited, has } \\
\text { resumed a normal life }\end{array}$ & Not reported & Spain \\
\hline
\end{tabular}




\section{Case Reports in Gastroenterology}

Case Rep Gastroenterol 2019;13:280-293

(C) 2019 The Author(s). Published by S. Karger AG, Basel www.karger.com/crg

Makowsky et al: Subcutaneous Magnesium Sulfate

Table 2. Summary of included reports describing subcutaneous magnesium administration (continued)

\begin{tabular}{|c|c|c|c|c|c|c|c|}
\hline Search & $\begin{array}{l}\text { Author, year of } \\
\text { publication }\end{array}$ & Design & Patients & Magnesium dose & $\begin{array}{l}\text { Influence on } \mathrm{Mg}^{2+} \text { and } \\
\text { symptoms }\end{array}$ & Adverse effects & Country \\
\hline $\mathrm{M} / \mathrm{E}$ & $\begin{array}{l}\text { Small et al. [14], } \\
2015 \\
\text { Small et al. [15], } \\
2015 \text { (update) }\end{array}$ & $\begin{array}{l}\text { Retrospective } \\
\text { review } \\
10 \text { years } \\
\text { Intestinal fail- } \\
\text { ure database at } \\
\text { St. Mark's Hos- } \\
\text { pital, Harrow, } \\
\text { United King- } \\
\text { dom }\end{array}$ & $\begin{array}{l}n=26 \text { ( } 19 \text { female; } \\
7 \text { male) patients from an } \\
\text { intestinal failure database } \\
\text { using home subcutaneous } \\
\text { fluid } \\
n=21 \text { had magnesium in } \\
\text { their infusions } \\
\text { Initial inpatient assess- } \\
\text { ment; patients taught to } \\
\text { self-administer fluids via } \\
\text { gravity subcutaneously } \\
\text { into the upper leg or abdo- } \\
\text { men } \\
n=32 \text { (22 female; } \\
10 \text { male) } \\
n=24 \text { had magnesium in } \\
\text { their infusions }\end{array}$ & $\begin{array}{l}\text { Mean of } 21 \pm 9.8 \text { (range } 8 \text { - } \\
40 \text { ) mmol per week } \\
\text { Sixteen had } 4 \text { mmol mag- } \\
\text { nesium per infusion } \\
\text { (Treatment duration: } 17.4 \\
\pm 34(3-139) \text { months } \\
\text { Five had } 8 \mathrm{mmol} \text { magne- } \\
\text { sium added/ } \\
\text { infusion. (treatment dura- } \\
\text { tion: } 10 \pm 8.5(2-24) \\
\text { months }\end{array}$ & $\begin{array}{l}M g^{2+}: \text { in } 2 \text { patients the } \\
\text { treatment did not cor- } \\
\text { rect magnesium levels } \\
\text { Symptoms: not re- } \\
\text { ported } \\
M^{2+}: \text { in } 3 \text { patients the } \\
\text { treatment did not cor- } \\
\text { rect magnesium levels }\end{array}$ & $\begin{array}{l}\text { Most patients } \\
(n=20 ; 77 \%) \text { had } \\
\text { no complications } \\
\text { Problems were } \\
\text { leaking at the infu- } \\
\text { sion site and the in- } \\
\text { fusion taking too } \\
\text { long }(>14 \mathrm{~h})\end{array}$ & $\begin{array}{l}\text { United King- } \\
\text { dom }\end{array}$ \\
\hline G & $\begin{array}{l}\text { Adgey et al. [16], } \\
2016\end{array}$ & $\begin{array}{l}\text { Retrospective } \\
\text { chart review } \\
\text { Intestinal fail- } \\
\text { ure unit of the } \\
\text { Belfast Trust } \\
\text { (9 years) }\end{array}$ & $\begin{array}{l}n=35 \text { patients who used } \\
\text { home subcutaneous fluids } \\
\text { over a 9-year period } \\
n=30 \text { (median age: } 56.5 \\
\text { yrs; } 53 \% \text { female) } \\
\text { had magnesium replace- } \\
\text { ment in their fluids } \\
87 \% \text { of patients had } \\
\text { Crohn's disease, ischemia } \\
\text { and post-operative compli- } \\
\text { cations }\end{array}$ & $\begin{array}{l}\text { Magnesium } 4 \text { mmol per } \\
\text { bag (with the volume of } \\
\text { the bag varying per pa- } \\
\text { tient) }\end{array}$ & $\begin{array}{l}M g^{2+}: \text { median magne- } \\
\text { sium concentrations } \\
\text { increased pre to } 1- \\
\text { month post: } \\
\text { pre: } 0.57 \mathrm{mmol} / \mathrm{L} \\
\text { (IQR: } 0.52-0.62) \\
\text { Post: } 0.78 \mathrm{mmol} / \mathrm{L} \\
(0.73-0.86)(p< \\
0.001) \\
\text { Symptoms: not re- } \\
\text { ported }\end{array}$ & $\begin{array}{l}\text { Two patients expe- } \\
\text { rienced cellulitis at } \\
\text { the needle site } \\
4 \text { other patients re- } \\
\text { quired admission } \\
\text { for dehydration } \\
1 \text { required home } \\
\text { parenteral nutri- } \\
\text { tion }\end{array}$ & $\begin{array}{l}\text { Northern } \\
\text { Ireland }\end{array}$ \\
\hline $\mathrm{M} / \mathrm{E}$ & $\begin{array}{l}\text { Fenning et al. } \\
{[17], 2017}\end{array}$ & Case report & $\begin{array}{l}n=1 \\
66 \text {-year-old female } \\
\text { Recurrent symptomatic } \\
\text { hypomagnesemia, on the } \\
\text { background of advanced } \\
\text { ovarian cancer and high- } \\
\text { output ileostomy }\end{array}$ & $\begin{array}{l}\text { Inpatient initial treatment } \\
\text { with } \\
20 \text { mmol magnesium sul- } \\
\text { fate IV; the next day she } \\
\text { started daily continuous } \\
\text { subcutaneous magnesium } \\
\text { ( } 8 \text { mmol magnesium sul- } \\
\text { fate [ } 4 \mathrm{~mL} \text { of magnesium } \\
\text { sulfate } 50 \% \text { injection] } \\
\text { made up to } 32 \text { mL with } \\
\text { water for injection to pro- } \\
\text { vide an isotonic solution; } \\
\text { delivered in a } 50 \text { mL sy- } \\
\text { ringe via a CME T34 } \\
\text { (McKinley syringe pump) } \\
\text { Outpatient therapy: con- } \\
\text { tinued continuous subcu- } \\
\text { taneous magnesium infu- } \\
\text { sion; blood levels checked } \\
\text { weekly then less fre- } \\
\text { quently } \\
\text { Duration: patient died } 2 \\
\text { months after discharge }\end{array}$ & $\begin{array}{l}M g^{2+} \text { : magnesium re- } \\
\text { mained stable } \\
\text { throughout her inpa- } \\
\text { tient stay ( } 0.83 \\
\text { mmol/L on discharge, } \\
6 \text { days after admis- } \\
\text { sion) } \\
\text { Symptoms: not re- } \\
\text { ported }\end{array}$ & $\begin{array}{l}\text { There were no } \\
\text { acute complica- } \\
\text { tions with deliver- } \\
\text { ing magnesium via } \\
\text { syringe pump }\end{array}$ & $\begin{array}{l}\text { United King- } \\
\text { dom }\end{array}$ \\
\hline
\end{tabular}

$\mathrm{Mg}^{2+}$, magnesium; M/E, Medline/Embase; S, Scopus; G, Google; yrs, years; PTH, parathyroid hormone. 


\section{Case Reports in Gastroenterology}

Makowsky et al.: Subcutaneous Magnesium Sulfate

Table 3. Summary of included reports describing subcutaneous magnesium administration (continued)

\begin{tabular}{|c|c|c|c|c|c|c|c|}
\hline Search & $\begin{array}{l}\text { Author, year of } \\
\text { publication }\end{array}$ & Design & Patients & Magnesium dose & $\begin{array}{l}\text { Influence on } \mathrm{Mg}^{2+} \text { and } \\
\text { symptoms }\end{array}$ & Adverse effects & Country \\
\hline \multicolumn{8}{|c|}{ Other medical conditions } \\
\hline S & $\begin{array}{l}\text { Aries et al. [18], } \\
2000\end{array}$ & Case report & $\begin{array}{l}\text { 28-year-old male with ab- } \\
\text { normal intestinal magne- } \\
\text { sium absorption; present- } \\
\text { ing with recurrent cerebral } \\
\text { seizures. Hypomagnese- } \\
\text { mia ( } 0.48 \text { mmol/ } \\
\text { L) despite daily IV magne- } \\
\text { sium infusion } \\
\text { Treated with continuous } \\
\text { magnesium infusion via in- } \\
\text { dwelling subcutaneous in- } \\
\text { fusion pump }\end{array}$ & $\begin{array}{l}\text { Not specified } \\
\text { Duration: not reported }\end{array}$ & $\begin{array}{l}M g^{2+} \text { : "normal serum } \\
\text { magnesium concen- } \\
\text { trations were at- } \\
\text { tained" } \\
\text { Symptoms: "all symp- } \\
\text { toms disappeared" }\end{array}$ & Not reported & $\begin{array}{l}\text { Germany } \\
\text { English ab- } \\
\text { stract } \\
\text { full text in } \\
\text { German }\end{array}$ \\
\hline S & $\begin{array}{l}\text { Weinbrenner and } \\
\text { Besser [19], } 2006\end{array}$ & Case report & $\begin{array}{l}\text { 27-year-old female with } \\
\text { generalized tonic clonic } \\
\text { seizures and hypomag- } \\
\text { nesemia with secondary } \\
\text { hypocalcemia (HSH syn- } \\
\text { drome) on oral magne- } \\
\text { sium supplementation }\end{array}$ & $\begin{array}{l}\text { Treated with "parenteral } \\
\text { application of magnesium } \\
82.5 \mathrm{mmol} / \mathrm{d}) \text { " } \\
\text { Unclear if dose provided is } \\
\text { IV or SC } \\
\text { Duration: not reported }\end{array}$ & $\begin{array}{l}M g^{2+} \text { : not reported } \\
\text { Symptoms: magne- } \\
\text { sium stopped her sei- } \\
\text { zure and normalized } \\
\text { her cerebellar signs } \\
\text { except for slight dys- } \\
\text { arthria, and that sub- } \\
\text { cutaneous magne- } \\
\text { sium supplementa- } \\
\text { tion kept her durable } \\
\text { free of her neurologic } \\
\text { symptoms }\end{array}$ & Not reported & $\begin{array}{l}\text { Germany } \\
\text { English ab- } \\
\text { stract, full } \\
\text { text in Ger- } \\
\text { man }\end{array}$ \\
\hline $\mathrm{M} / \mathrm{E}$ & $\begin{array}{l}\text { Pirrello et al. [20], } \\
2007\end{array}$ & $\begin{array}{l}\text { Retrospective } \\
\text { case series }\end{array}$ & $\begin{array}{l}n=32 \text { hospice patients } \\
\text { treated with hyaluroni- } \\
\text { dase for facilitation of hy- } \\
\text { podermoclysis and medi- } \\
\text { cation infusion } \\
n=1 \text { patient received sub- } \\
\text { cutaneous potassium and } \\
\text { magnesium supplementa- } \\
\text { tion } \\
\text { added to their hydration } \\
\text { fluid for } 2 \text { days }\end{array}$ & $\begin{array}{l}\text { Potassium } 20 \mathrm{mEq} / \mathrm{L} \text { and } \\
\text { magnesium } 1 \mathrm{~g} / \mathrm{L} \\
\text { Duration: } 2 \text { days }\end{array}$ & $\begin{array}{l}\mathrm{Mg}^{2+}: \text { not reported } \\
\text { Symptoms: not re- } \\
\text { ported }\end{array}$ & $\begin{array}{l}\text { No skin irritation } \\
\text { noted }\end{array}$ & $\begin{array}{l}\text { United } \\
\text { States }\end{array}$ \\
\hline$S$ & $\begin{array}{l}\text { Sanda et al. [21], } \\
2008\end{array}$ & Case report & $\begin{array}{l}n=1 \\
2 \text {-year-and-8-month-old } \\
\text { female child with severe } \\
\text { hypocalcemia and hypo- } \\
\text { magnesemia secondary to } \\
\text { activating calcium sensor } \\
\text { receptor mutation } \\
\text { Treatment with teripar- } \\
\text { atide and continuous sub- } \\
\text { cutaneous magnesium sul- } \\
\text { fate via infusion pump }\end{array}$ & $\begin{array}{l}\text { Not specified } \\
\text { Duration: not reported }\end{array}$ & $\begin{array}{l}M g^{2+} \text { : she responded } \\
\text { well to adjunctive } \\
\text { therapy with continu- } \\
\text { ous subcutaneous } \\
\text { magnesium } \\
\text { Symptoms: not re- } \\
\text { ported }\end{array}$ & Not reported & $\begin{array}{l}\text { United } \\
\text { States }\end{array}$ \\
\hline
\end{tabular}

$\mathrm{Mg}^{2+}$, magnesium; M/E, Medline/Embase; S, Scopus; G, Google; yrs, years; PTH, parathyroid hormone. 


\section{Case Reports in Gastroenterology}

Makowsky et al.: Subcutaneous Magnesium Sulfate

Table 4. Summary of included reports describing subcutaneous magnesium administration (continued)

\begin{tabular}{|c|c|c|c|c|c|c|c|}
\hline Search & $\begin{array}{l}\text { Author, year of } \\
\text { publication }\end{array}$ & Design & Patients & Magnesium dose & $\begin{array}{l}\text { Influence on } \mathrm{Mg}^{2+} \text { and } \\
\text { symptoms }\end{array}$ & Adverse effects & Country \\
\hline $\mathrm{M} / \mathrm{E}$ & $\begin{array}{l}\text { Bock and Roth } \\
{[22], 2013}\end{array}$ & Case report & $\begin{array}{l}27 \text {-year-old with severe } \\
\text { refractory hypomagnese- } \\
\text { mia to oral and IV magne- } \\
\text { sium } \\
\text { Required almost weekly IV } \\
\text { magnesium infusions to } \\
\text { keep her plasma magne- } \\
\text { sium levels } \geq 0.3 \text { mmol/L } \\
\text { below which she devel- } \\
\text { oped paresthesia and } \\
\text { cramps } \\
\text { Continuous infusion of } \\
\text { subcutaneous magnesium } \\
\text { via portable insulin pump }\end{array}$ & $\begin{array}{l}\text { Insulin pump; } 3 \mathrm{~mL} \text { pump } \\
\text { reservoir filled with undi- } \\
\text { luted } 50 \% \text { magnesium } \\
\text { sulfate solution; infusion } \\
\text { rate } 0.1 \mathrm{~mL} / \mathrm{h} \text { to deliver } \\
4.8 \mathrm{mmol} \text { magnesium per } \\
\text { day } \\
\text { Catheter replaced q2-3 } \\
\text { days } \\
\text { Duration: at least } \\
6 \text { months }\end{array}$ & $\begin{array}{l}M g^{2+} \text { : serum magne- } \\
\text { sium increased and } \\
\text { remained at mean } \\
0.52 \text { mmol/L over } 6 \\
\text { months }( \pm 0.06 \mathrm{SD}) \\
\text { Symptoms: paresthe- } \\
\text { sia, cramps and diar- } \\
\text { rhea secondary to } \\
\text { oral magnesium sup- } \\
\text { plements subsided }\end{array}$ & $\begin{array}{l}2 \text { episodes of sub- } \\
\text { cutaneous infection }\end{array}$ & $\begin{array}{l}\text { Switzerland } \\
\text { conference } \\
\text { abstract }\end{array}$ \\
\hline S & $\begin{array}{l}\text { Vermeulen et al. } \\
{[23], 2017}\end{array}$ & Case report & $\begin{array}{l}n=1 \\
\text { 39-year-old female } \\
\text { Severe uncontrolled and } \\
\text { irreversible hypomagnese- } \\
\text { mia secondary to cisplatin } \\
\text { treatment in childhood; } \\
\text { unresponsive to oral ther- } \\
\text { apy, IV and IM therapy also } \\
\text { trialed } \\
\text { Also had trials of low-salt } \\
\text { diet, acetazolamide, ami- } \\
\text { loride, hydrochlorothia- } \\
\text { zide) } \\
\text { The cause was identified to } \\
\text { be irreversible damage to } \\
\text { the distal tubules as the } \\
\text { site of magnesium loss } \\
\text { Continuous subcutaneous } \\
\text { magnesium via insulin } \\
\text { pump }\end{array}$ & $\begin{array}{l}\text { Inpatient therapy: magne- } \\
\text { sium sulfate } 50 \% \text { was } \\
\text { combined with lidocaine } \\
2 \%(2: 1 \text { ratio }) \text { resulting in } \\
5 \mathrm{~g} \mathrm{Mg} \text { sulfate } / 24 \mathrm{~h} \\
\text { Outpatient therapy: } \\
10 \mathrm{~mL} \text { magnesium sulfate } \\
50 \% \text { with } 3 \mathrm{~mL} \text { lidocaine } \\
2 \% \text { running at } 0.6 \mathrm{~mL} / \mathrm{h} \\
\text { Lidocaine was used to } \\
\text { prevent pain at the inser- } \\
\text { tion site, and the subcuta- } \\
\text { neous needle insertion } \\
\text { site was switched regu- } \\
\text { larly } \\
\text { Duration: }>2 \text { years of fol- } \\
\text { low-up }\end{array}$ & $\begin{array}{l}M g^{2+} \text { : magnesium val- } \\
\text { ues normalized } \\
\text { Symptoms: most but } \\
\text { not all symptoms } \\
\text { were reported to have } \\
\text { responded well to } \\
\text { therapy } \\
\text { Level of energy, mus- } \\
\text { cle cramps, paresthe- } \\
\text { sia, hyperventilation, } \\
\text { agitation, painful } \\
\text { bones and fainting im- } \\
\text { proved remarkably } \\
\text { Palpitations, light } \\
\text { headedness, rigid } \\
\text { muscles and insomnia } \\
\text { did not show an ap- } \\
\text { parent improvement }\end{array}$ & $\begin{array}{l}\text { Inpatient therapy: } \\
\text { well tolerated by } \\
\text { the patient with ac- } \\
\text { ceptable local and } \\
\text { no systemic side ef- } \\
\text { fects } \\
\text { Long-term outpa- } \\
\text { tient therapy: mild } \\
\text { skin lesions at the } \\
\text { insertion site and } \\
\text { non-painful indu- } \\
\text { rated areas }\end{array}$ & Netherlands \\
\hline
\end{tabular}

$\mathrm{Mg}^{2+}$, magnesium; M/E, Medline/Embase; S, Scopus; G, Google; yrs, years; PTH, parathyroid hormone. 